\title{
Asian states link to popularize science...
}

[ISLAMABAD] Seven south Asian states, including some of the world's poorest countries, have agreed to pool their ideas and expertise to raise the public awareness of science in their region.

Representatives from countries including India, Pakistan and Sri Lanka agreed at the end of a five-day workshop on science popularization last month to set up a regular forum to exchange experiences of incorporating science into programmes on public health, literacy and rural development.

They pledged to hold an annual regional science festival, set up a student exchange programme and investigate setting up a peercommunication in south Asian countries.

The meeting also recommended that state-controlled media networks be required to allocate ten per cent of air-time to sciencerelated programmes, and that one per cent of this should be during peak audience time.

The meeting, held in Islamabad, was organized by the Pakistan Science Foundation and the South Asian Association for Regional Cooperation (SAARC), an intergovernmental body made up of India, Pakistan, Bangladesh, Sri Lanka, Nepal,

SAARC exists partly to improve trade, reviewed journal of science and development Maldives and Bhutan.

cultural and scientific links between member states. Some SAARC countries, however, although neighbours, have tense relations, and delegates expressed concern that these differences may hinder practical cooperation.

For example, India and Pakistan cannot exchange television and radio programmes on science because broadcasts from each country are banned in the other.

Many Pakistani delegates said they considered India's approach to the public understanding of science more relevant to Pakistan's needs. But they said they could never say this in public as it would be too politically sensitive. SAARC governments do not want India to be seen as the region's superpower.

In general, India and Pakistan approach the popularization of science with different aims. Pakistan has adopted what is known as the 'deficit' model, which focuses on helping people to acquire more knowledge about modern scientific developments.

Pakistan's science planners have modelled their country's science promotion activities on those of developed countries. They are based around museums, planetariums and mobile exhibitions, and assume a single target audience who can read and write.

India, on the other hand, has adopted a more indigenous approach. For example,

\section{....and India's young get a taste for research}

[ISLAMABAD] Next January, while the senior figures of Indian science gather for the National Science Congress in Madras, the city will be hosting a parallel science congress for children.

For the past five years, India's National Council for Science and Technology Communication (NCSTC) has been experimenting with an unusual method of science communication. Children from schools in almost every district of India are being encouraged to undertake research projects. The best are shown at the annual children's congress.

The idea, says B. K. Tyagi of the NCSTC, is to give children a feel for how science works, to encourage them to consult experts, "and to show them that they can use the tools of research to change their own lives".

This year, some 11,000 schools from 450 districts are

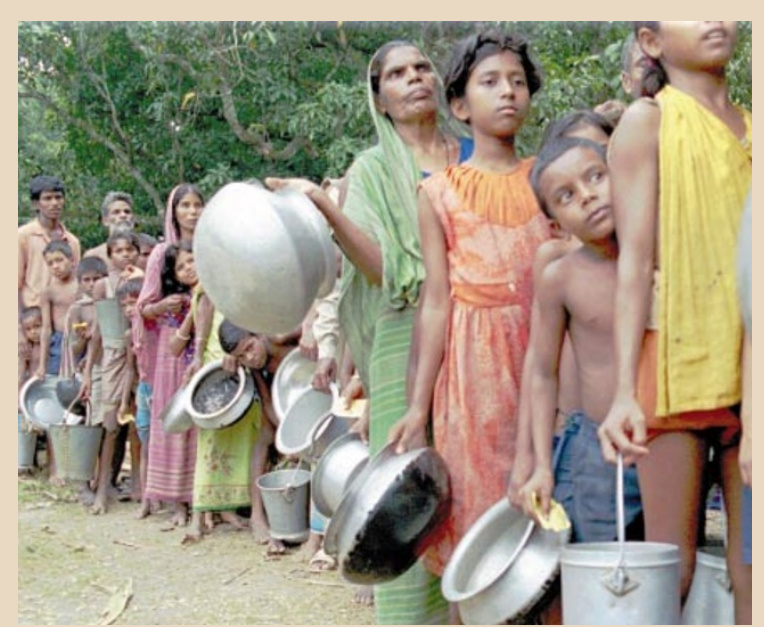

Tapping into schools: children are combating water pollution. taking part. Projects can be submitted in any of India's 18 official languages. They are assessed according to four criteria: the nature of the problem, its relevance to local communities, the quality of the written report, and the oral presentation.

Tyagi says that, unexpectedly, schools in rural areas come up with some of the more innovative projects. One 13-year-old identified and eliminated the source of contamination in his village stream.

Elsewhere, children monitored air-pollution levels and persuaded the local authorities to take remedial action. planetariums are rarely used in promoting an understanding of astronomy. Children are encouraged instead to build their own telescopes, even down to grinding the mirrors.

"A planetarium is useful in European countries where the sky tends to be cloudy. But in India we have clear night skies for most of the year," says B. K. Tyagi of India's National Council for Science and Technology Communication.

India has also tailored its activities according to its audience. Some of its science popularization activities are aimed only at literate people, and others at those unable to read and write. A third category — which includes campaigns against smoking, drugs and alcohol - targets a general audience.

Science promotion among illiterate rural populations is largely information based. For example, people are taught how to weigh and measure, how to test water quality, and how to become blood donors.

Those who can read and write are encouraged to acquire research skills in addition to facts. They are also given opportunities to use these skills to tackle important local concerns, such as reducing air pollution and improving the quality of the water supply (seebox).

Delegates at the workshop recalled many experiences that were common across the SAARC region. These include the problem of communicating science without challenging concepts of religious faith, which remains strong in all SAARC countries.

Science communicators in some SAARC countries are hesitant about raising issues they think will bring them into conflict with religious beliefs. This is particularly true of Pakistan, a Muslim country, where human evolution is rarely discussed in public.

One Pakistan Television executive at the workshop said that, when covering the issue of cloning, he had to take care that the network could not be seen to be promoting the idea.

Delegates were generally critical of the media in their countries. The exception was All India Radio, which regularly broadcasts science programmes. The print media was criticized for ignoring local science and instead publishing syndicated articles from international news agencies.

Delegates spoke of the marked interest shown by ordinary citizens in defence science and technology. This could be a consequence of the region's troubled politics. For example, the media in India and Pakistan devote much space to nuclear issues.

Aleem Ahmed, the editor of the Urdu-language science monthly Global Science, which is based in Karachi, says that editions of the magazine that focus on defence or nuclear matters outsell those on other topics.

EhsanMasood 